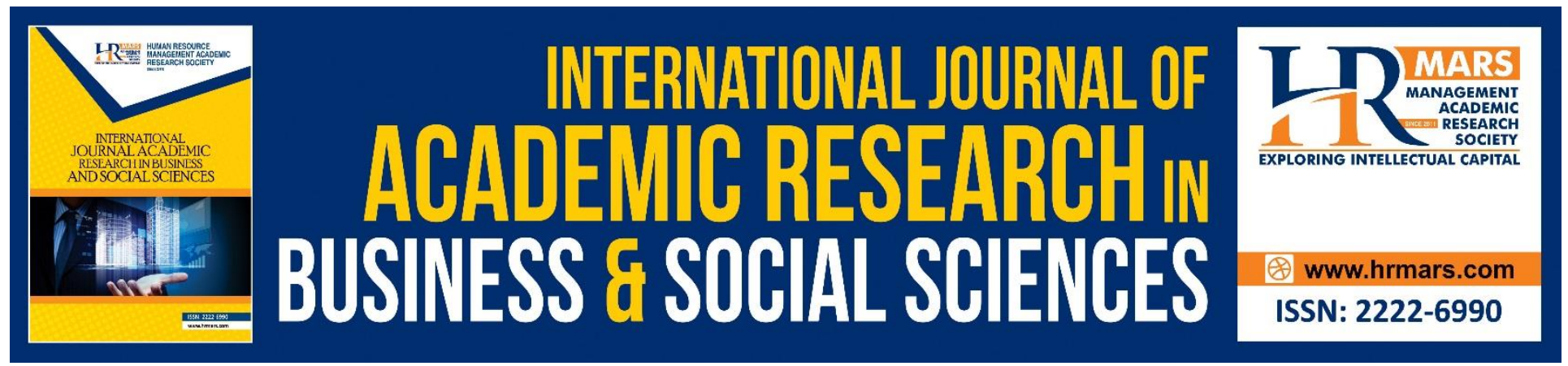

\title{
The Non-Domestic Roles of the Malay Women According to the Sunnah
}

\section{Roshimah Shamsudin}

To Link this Article: http://dx.doi.org/10.6007/IJARBSS/v9-i1/5386

DOI: $\quad 10.6007 /$ IJARBSS/v9-i1/5386

Received: 22 Dec 2018, Revised: 17 Jan 2019, Accepted: 24 Jan 2019

Published Online: 28 Jan 2019

In-Text Citation: (Shamsudin, 2019)

To Cite this Article: Shamsudin, R. (2019). The Non-Domestic Roles of the Malay Women According to the Sunnah. International Journal of Academic Research in Business and Social Sciences, 9(1), 2059-2067.

Copyright: (C) 2019 The Author(s)

Published by Human Resource Management Academic Research Society (www.hrmars.com)

This article is published under the Creative Commons Attribution (CC BY 4.0) license. Anyone may reproduce, distribute, translate and create derivative works of this article (for both commercial and non-commercial purposes), subject to full attribution to the original publication and authors. The full terms of this license may be seen

at: http://creativecommons.org/licences/by/4.0/legalcode

Vol. 9, No. 1, 2019, Pg. 2059 - 2067

http://hrmars.com/index.php/pages/detail/IJARBSS

JOURNAL HOMEPAGE

Full Terms \& Conditions of access and use can be found at http://hrmars.com/index.php/pages/detail/publication-ethics 


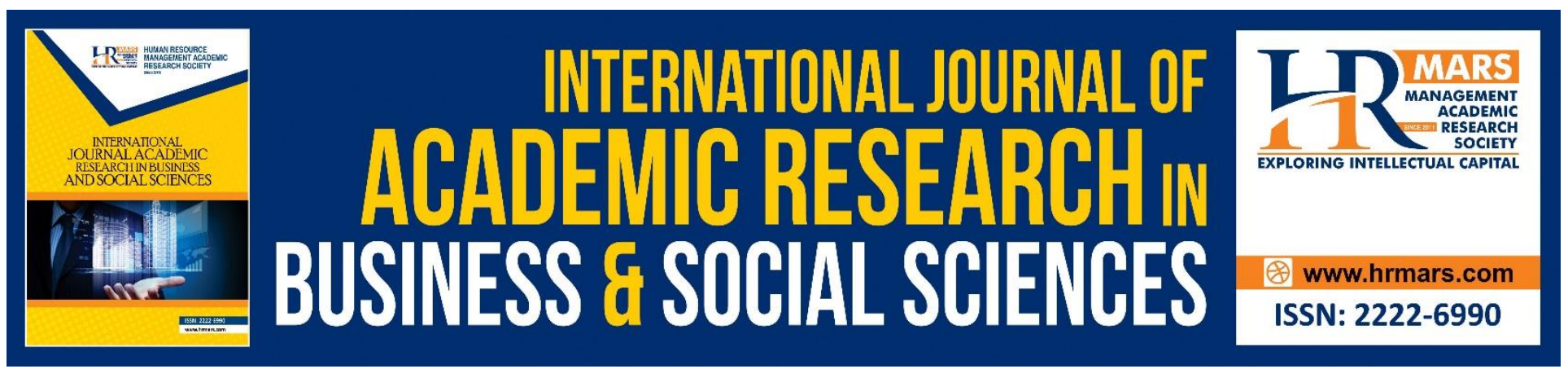

\title{
The Non-Domestic Roles of the Malay Women According to the Sunnah
}

\author{
Roshimah Shamsudin \\ School of Humanities, Universiti Sains Malaysia \\ Email: roshimah@usm.my
}

\begin{abstract}
Studies on Malay women conducted by both the local and the western researchers indicate that the scientific research does not marginalize women issues. The women theme often revolve around their roles in education, economy, social and politic. These roles are studied from a few angles such as history and Islamic view. Despite the efforts in studying the roles of women from the Islamic perspective in particular in politics and leadership, there is still plenty of room for studies pertaining to the non-domestic roles espoused by the Sunnah. This research is therefore aimed to study the non-domestic roles played by the Malay women and further analyzing their roles in accordance to the authorities found in the hadiths. The data pertaining to their roles acquired through library research are derived from historical materials while the hadith that were referred to were sourced from the major hadith works in particular the al-Kutub al-Sittah. The finding shows that the Malay women are not prevented from assuming roles outside their homes. This is in line with the hadith of the Prophet (peace be upon him) which allows women of the day to be involved in various matters outdoor.
\end{abstract}

Keywords: Non-domestic, roles, rights, Malay women, al-Sunnah.

\section{Introduction}

Women's roles are naturally associated with the management of household activities thus, there is no surprise that the traditional Malay community in general view home as the rightful place for women. They are regarded as the cook and caretaker of the home and the family members (Ishak Saat, 2011). Hence, the Malay women are seen as wives and mothers who are tasked to meet the need of husbands, encompassing provision of food, clothing and other necessities (Khalijah Mohd Salleh, 1994). The same can be said of the role of mothers that requires them to answer the daily needs of the children in various matters such as education and care. Consequently their roles in family resulted in acknowledgment and appreciation by the religion and the community (Fatimah Hassan, 2011). 
But the view that restricts the roles of women at home per se is gradually changing with the advent of time. Ishak Saat (2011) relates the change of viewpoint with the political development that followed the outbreak of the $2^{\text {nd }}$ world war, specifically with the emergence of women's liberation cause that echoed worldwide with no exception to Malaya. Fatimah Abdullah (1985) on the other hand associates the industrialization and urbanization as the two pivotal processes that had implicated the roles of women which resulted in the increase of women work force. Although the view on women's roles had changed, there are still some whose opinions are intact that Islam does not offer extra space for women to enjoy the rights they have, unlike that of the men. This opinion was voiced by Wazir Jahan Karim (Mahani Musa, 2005).

On the contrary, Muhammad Fadli Mohammed Fawzi (n.d) opines that Islam does not limit the roles of women merely at home, instead Islam is the one religion that recognizes high positions for women and confers appropriate rights to engage in public space activities. To the latter, the view that limits the Muslim women's involvement in public domain as subject to circumstances and needs, and not to be exercised freely is not backed by Quranic injunctions or al-hadith authority to impose their opinions.

As such this writing is intended to discuss the non-domestic roles and rights of the women, in particular the Malays. These roles and rights will be analyzed from the perspective of al-Sunnah by submitting the relevant texts of the hadith quoted by the distinguished hadith scholars. It is the researcher's ardent hope that the analysis could paint a clearer picture on what rights and roles Islam intends for the women to have outside the domain of their homes as laid down by the hadiths. This study shall not present the whole available hadiths of the Prophet (peace be upon him) that speak on women's rights and roles but instead would only concentrate on a few chosen ones which express the aspects such as politics, employment, education and social.

\section{The Political Role of the Malay Women.}

Often time, the available writings on women concentrate on their roles in politics. According to Ishak Saat (2011), the fold of history saw significant roles played by Malay women in inciting the movement for independence of Malaya. The setting up of Angkatan Wanita Sedar (AWAS) partook by the women together with the emergence of female figures the likes of Khadijah Sidek, Shamsiah Fakeh, Aishah Ghani, Sawiyah Jalil and Sakinah Junid had clearly validated the role of women in politics. In fact they were deemed to have the force and voice which resulted in their cause to be outlawed by the British. The participation of women in politics is seen by the Western scholars as originating from the rib of men which results in their development to be seen as determined by the leadership of men. To that Mahani Musa (2005) disagrees. She opines that some involvement of women originated from their own maturity and self-awareness to fight in the cause of liberation from the yokes of the colonials, thereby dismissing the earlier views of the Western Scholars. The women in fact essentially worked together alongside the men in the political and social struggle.

The non-domestic role of women in politics did not find its root from the struggle for independence from the British per se but it traversed far back in time. The research by Mahani Musa (2005) proves that the women had never been docile but quite on the contrary had been involved in the politics of the palace courts, albeit playing the roles from the behind scenes whilst some had been headed sovereign governments. Hence, women were not marginalized. Nevertheless, the number of women 
in politics is dwarfed by that of men. This phenomena is particularly so coming from the system intrinsic in the Malay culture which leaves women behind in all aspects of live save the domestics ones. Rigid and narrow interpretations of the scriptures had caused women to be denied their extensive rights and roles. Thus, the Muslim community is urged to return the true interpretations of the roles and rights of the muslim women back to them in accordance to religion.

The above discussion clearly demonstrates the role of Malay women in the political sphere they have embarked on from the traditional times right up to the demands of the struggle for independence. In truth, the role of the Malay women had never been ceased, instead it lasts to this day of age.

\section{The Socio-Economical Roles of the Malay Women.}

Similar to politics, the Malay women play a vital role socio-economically. They have been involved in commerce long before the colonial days that their contribution must not be underestimated. This is particularly so according to Nadiah Ismail (2011) who views women as the key worker in all occupations as enshrined in the Kedah Rules.

Women too since the Malaccan Sultanate era had been entrepreneurs whether in night market or by the roadside. Apart from that, women were also involved in providing services on voyages; for example, working on board, sale helpers or fulfilling the sexual needs. Meanwhile, what happens in the east coast in particular the state of Terengganu demonstrates that women shoulder multitudes of responsibility as workers, entrepreneurs, hawkers and in other occupations that the household matters were ignored. Equally is the state of Kelantan whereby business are dominated by the women. This is evident that entrepreneurship runs in the blood of most Malay women since time immemorial (Mahani Musa, 2005). They venture into various form of businesses in order to generate the economy. From the copra trade to canteen food business. The proceeds of these businesses were used by the Malay women in the past to perform Hajj in Mecca (Aiza Maslan \& Roshimah Shamsudin, 2011).

Apart from businesses, the Malay women were involved in paddy planting. Kedah for instance, recognizes the contributions of female Malays of common people in the agricultural sector in the state. As a matter of fact, a lot of Malay women in this state own plantation lands. In this respect, they are deemed to be working harder than their male counterparts in all aspects. As such, there is no surprise that they are ahead in the realm of land ownership. From paddy plantation, the Malay women embarked upon rubber plantation in light of rubber price hike from 1924 to 1926. Intrinsically, the Malay women of Kedah were acknowledged as the main contributors towards the economy stability of their families as well as that of the state (Nadiah Ismail, 2011). At present, the Malay women are getting more advanced in employment. Many are highly educated and assume numerous high ranking posts (Muhammad Fadli, n.d).

\section{Malay Women Roles in Education.}

The participation of Malay women in pre-independent education were tightly associated with the British policy as well as the mentality of the Malay community of bygone era. The British did not give emphasis on women education. This is apparent from their education policy which only target at making the Malay women as good housewives to educated Malay men. Besides, the British had a 
viewpoint that education for women did not contribute towards the economy. As such, they were not resolute in developing educations for the Malay women (Mahani Musa, 2005).

As for the Malays they are of the view that education for daughters was not important. This view is relative to their notion that saw women's role is limited to household minder/keeper and not as the bread winner. As a result the daughters were placed under strict control of their parents and customs. This stringent perception did not change even after the end of the $2^{\text {nd }}$ world war. Furthermore, the Malays community did not encourage or welcome modern education. Apart from believing that the modern education has its roots in Christianity, the Malays were concerned of the free association between the males and females. The women were also not keen to get education themselves. However, this does not mean that women were barred from getting education. They on the other hand were sent to study the al-Quran. Despite their small numbers, fewer still managed to complete their education on account of marriage and helping out the family. In reality however, the awareness of the need for education had been apparent before the advent of the twentieth century. In Kedah for example, the pondok education was prevalent even before the arrival of the British thereby signifying that the Malays at that material time had already given emphasis on religious studies (Mahani Musa, 2005).

However, the formal education at school as well was not rejected which initiatives could be seen in the setting up of schools including all girls schools (Mahani Musa, 2005). Unfortunately, despite the welcome of formal education for females, it did not extend to higher level pursuit for education (Khalijah Mohd Salleh, 1994).

The present scenario sees the women as advanced in education having furthered their studies to higher level. This is an evidence of a paradigm shift in women's education which had an unwelcoming past wherein the women were emplaced in the kitchen. This observation was recorded by Khalijah Mohd Salleh (1994) in her writing:

In today's situation, women of our time attained educations and qualifications and recognize the true potentials of their selves... women in the 90s decade had reached better positions to previous decades. In the 50s and 70s we hear slogans that home is where the women should be, nowdays the call had been less and lesser audible."

\section{Analysis of the Hadith Pertaining to the Roles and Rights of Women.}

Basically there are a few hadiths that speak about the role of women which is responsible for the wellbeing of household matters. One such hadith is an authentic one, narrated by al-Bukhari and Muslim;

"... and a woman is the leader of the house members of her husband and the children of her husband and she is responsible upon them" (Bukhari, 2015, Muslim, n.d)

Ibn Hajar (2011) when commenting on this hadith opines that the female roles revolve around four categories, namely:

1. Managing the household affairs

2. Managing the children

3. Giving service to the household members

4. Advising the husband in the aforementioned roles. 
The scholar however does not elaborate on the form and scope of service and extent of management that the women are bound by in minding their households. In the context of home leadership, the wives are the individuals responsible for safeguarding the honour the best possible way, required to be fair, doing good beneficial deeds and to not cross the boundary in doing so unless permitted by shara'. The said hadith also speaks out that a wife is not to spend the means of her husband's without the latter's consent. It also describes that each and individual women is a leader although she does not have a husband, a helper or a child. One is a leader unto one's limbs and body by doing the recommended and abandon the prohibited deeds which may be in the form of conversation, actions and beliefs. In this sense, that is how that individual leads oneself (Ibn Hajar, 2011).

Apart from the above, Ibn Hajar (2011) further opines that a woman's leadership is bound and limited to her husband's home. Because a wife is not supposed to be elsewhere than her husband's home unless with a special permission. This signifies that the husband's consent is the utmost importance to the wife. Al-Mubarakfuri (2003) on the other hand while scrutinizing the said hadith, mentions that a woman is in charge of administering the life well, advising the husband, showing of love and affection, being trustworthy, safeguarding herself and her husband's property and honour in the latter's absence, her husband's children as well as the latter's guests.

In this sense, the wife is responsible in the household by discharging the above said matters. As such, it is clear that the Malay's sentiment that sees the women as the minders of the households precisely coinciding with the authentic hadith of the prophet (peace be upon him). Apart from the hadith which dictates the domestic roles upon women, there are others that speak about involvement of women of the time of the Prophet in matters outside the perimeters of her husband's home as evidenced by the story of Asma' bint Abu Bakr who is the wives of Zubair bin al-'Awwam recorded in Sahih alBukhari. The hadith briefly means I carry the tamar seeds from the land of al-Zubair. The land was a war booty award from the prophet who awarded lands to whomever so desired including Zubair whose land prior to the war belonged to Banu Nadir (Ibn Hajar, 2011).

Al-Nawawi (2014) discusses in further length about the above interpretation by presenting another hadith which resonates the same tone but with longer text to Sahih al-Bukhari. The chores done by Asma' such as handling her husband's horse, minding the household of her husband, tending to the plantations and others as expressed in the above hadith, according to al-Nawawi are known to have been done by Asma'. Al-Nawawi further states that women equally perform such tasks in servitude to their husbands much as Asma' had done such as bread making, cooking, cleaning, laundering and others.

All their tasks were voluntarily done as charity from the wives to the husbands thereby forming a kind of good deeds to the husbands. He further emphasizes that women are not obliged to perform all the domestic chores, in fact, on the contrary, should a wife refuses to do all the chores, she is not condemned in sin. It is on the basis of pure normalcy and good custom that all these domestic tasks were voluntarily done. In fact, it is not even a pre-requisite to make it normalcy. However since performing the domestic tasks constitutes a form of good custom, hence the women had been doing the chores since old time to date. The obligation of women according to al-Nawawi (2014) consists of two substances; namely to make herself available to serve her husband and secondly to get herself familiarized in the house of her husband. This hadith illustrates that women at the time of the prophet 
were not prohibited to assume roles outside of their homes. As such, the non-domestic roles played by the women out of their houses are not in conflict with the authentic hadiths.

Apart from that there are a number of hadith that speak about the involvement of women in war efforts by the Prophet (peace be upon him). The hadith reads as follows;

"We go to war giving drinks to the fighters and we serve them and bring the dead and the injured back to Madinah". (Bukhari, 2015)

The above hadith according to Ibn Hajar (2011) demonstrates that women are required to care for the wounded fighters in time of emergency such as war. Perhaps this event occurred before the hijab obligation or perhaps the women engaged as first-aid in warfare were meant to treat only their husband or mahram. Therefore treatment is indispensable at a time of emergency at a reasonable extent. Al-Nawawi (2014) in discussing the hadith that women during prophetic period are allowed to engage in war efforts as they provided beneficial service from the aspects of serving drinks, firstaids and others. First-aids treatments were exclusively performed on respective mahrams only. This is to ensure that they are not exposed to close contact with non-mahram males except for out of necessity situations.

Meanwhile, al-Mubarakfuri (2003) took it that this hadith is authoritative enough to support the proposition that women are allowable to join the war efforts subject to certain appropriate roles as mentioned in the above Hadith. Jihad is not obligatory upon women. Thus it could be inferred that the roles played by the Malay women outside their homes in arenas that needed their service are based on the above authentic hadith. However they still are required to strictly guard their honours, one of which way is to cover their awrah during interactions with non-mahram of the opposite gender.

The political roles of women at the time of the Prophet (peace be upon him) were largely attributed to the action of one of the wives of the prophet, namely Ummu Salamah during the Hudaibiyyah Covenant and Hajj Wada'. Ibn Hajar (2011) in the tanbih section explains that Ummu Salamah gestured to the Prophet to shave prior to the companions who pledged tawaqquf to shave on account of sorrow for not having the opportunity to perform Hajj in that year. Ummu Salamah requested that the prophet to first exit from the gathering and requested that the Prophet not to speak to any of the companion. The suggestion of Ummu Salamah had caused the companions to emulate the prophet and shaved their heads. As such, Ibn Hajar further states that it is recommended to ask for opinion from respectable women. This shows that Ummu Salamah was endowed with brilliance.

\section{Conclusions}

The non-domiciled roles played by the Malay women outside the perimeter of their homes in politics, socio-economy and education are found to have not contradicting the Islamic teaching as ensh rined in the hadiths of the Prophet (peace be upon him). It is in line with the discussed hadiths which express that women during the prophetic time were not forbidden to engage in outside home activities in particular, the hadith which depicts Asma' working from outside of home; to the extent of participation in politics as highlighted by Ummu Salamah. The same applies to the Malay women who had since long been involved in politics, socio-economy and education. This indicates that women of any era, either from the prophet's time or of more recent time the like of the Malay women have their own roles that which are undeniable; in spite of competition with the men. Although the 
INTERNATIONAL JOURNAL OF ACADEMIC RESEARCH IN BUSINESS AND SOCIAL SCIENCES

Vol. 9, No. 1, Jan, 2019, E-ISSN: 2222-6990 @ 2019 HRMARS

phrase used is competition; it does not mean that the women were forbidden from having nondomestic roles but intrinsically theirs are of supportive roles, befitting that of women tendency; that is in administering the household affairs. However, where the situation necessitates it, women are not confined to the roles of domestic sphere but are even allowed to engage in politics, educations and economy as can be seen from the hadiths that had been analyzed. The same observation is exactly emulated by the Malay women. Thus it can be concluded that Islam does not marginalize women, much less confine them.

As such, this paper provides an important contribution on the efforts to analyze the roles of Malay women outdoors in the fields of politics, socio-economy and educations based on the perspective of the above-discussed hadiths. The findings of this study has greatly enhanced the existing research on the roles of Malay women in these areas thereby giving an impression that it is generally in accordance with the will of the hadiths. However there are still room for finer research as to whether or not the extent to which their involvements in these acceptable areas coincide with the hadiths in particular in respect of proper attire and association with the men. As a result, this paper proposes that the involvement of the Malay women outside the home although allowed by shara', it is subject to the guidelines on ethics and dress code as well as association with the men laid out in the hadith and these guidelines should be observed in order to conform to the true teachings of Islam.

\section{References}

Aiza, M. \& Roshimah, S. (2011). Penglibatan kaum wanita dalam institusi haji : satu sorotan sejarah. In Ishak Saat \& Nazarudin Zainun (Eds.). Wanita dan perjuangan. (1 ${ }^{\text {st }}$ ed., pp. 49-72). Johor: Penerbit UTHM.

Al-Bukhari, M. I. (2015). Sahih al-bukhari. Muhammad Zuhayr b. Nasir al-Nasir (ed.). Beirut : Dar Tawq al-Najah.

Al-Mubarakfuri, M.A.R. (2003). Tuhfah al-Ahwadhi Syarh Jami' al-Tirmidhi. Amman, Jordan : Bayt alAfkar al-Dawliyah.

Al-Nawawi, M. D. (2014). Al-Minhaj syarah sahih muslim (Khalil Ma'mun Shiha, Ed.). Beirut: Dar alMa'rifah.

Fatimah, A. (1985). Wanita dan pekerjaan: satu analisis konflik peranan. Akademia, 27, pp. 77-98.

Fatimah, H. (2011). Kejayaan wanita dalam program pembasmian kemiskinan luar bandar Malaysia : kajian kes Projek Amanah Ikhtiar Malaysia. In Ishak Saat \& Nazarudin Zainun (Eds.). Wanita dan perjuangan. (1 ${ }^{\text {st }}$ ed., pp. 73-98). Johor: Penerbit UTHM.

Ibn Hajar, A. A. M. (2011). Fath al-Bari Syarh Sahih al-Bukhari (Abd al-Aziz b. Abdullah b. Baz, Ed.). Beirut: Dar al-Fikr.

Ishak, S. (2011). Peranan wanita dalam gerakan kiri. In Ishak Saat \& Nazarudin Zainun (Eds.). Wanita dan perju angan. (1 ${ }^{\text {st }}$ ed., pp. 1-28). Johor: Penerbit UTHM.

Khalijah, M. S. (1994). Women in development. Kuala Lumpur : Institusi Kajian Dasar.

Mahani, M. (2005). Sejarah \& sosioekonomi wanita melayu Kedah 1881-1940. Bangi, Selangor: Penerbit Universiti Kebangsaan Malaysia.

Muslim, A. H. Q. (n.d.). Sahih muslim (Muhammad Fu'ad 'Abd al-Baqi, Ed.). Beirut: Dar Ihya' al-Turath al-'Arabi. 
INTERNATIONAL JOURNAL OF ACADEMIC RESEARCH IN BUSINESS AND SOCIAL SCIENCES

Vol. 9, No. 1, Jan, 2019, E-ISSN: 2222-6990 @ 2019 HRMARS

Muhammad, F. M. F. (n.d.) Peranan wanita di dalam sejarah melayu Islam. Retrieved from https://www.thereadinggroup.sg/Articles/Peranan\%20wanita\%20dalam\%20sejarah\%20Melayu $\%$ 20Islam.pdf.

Nadiah. I. (2011). Wanita melayu Kedah dan pemilikan tanah. In Ishak Saat \& Nazarudin Zainun (Eds.). Wanita dan perjuangan. (1 ${ }^{\text {st }}$ ed., pp. 27-48). Johor: Penerbit UTHM. 